\title{
STUDIES ON THE HELMINTH FAUNA OF JAPAN -Part 54. TREMATODES OF FISHES, XIII-
}

\author{
$\operatorname{AUTHOR}(\mathrm{S}):$
}

Yamaguti, Satyu

\section{CITATION:}

Yamaguti, Satyu. STUDIES ON THE HELMINTH FAUNA OF JAPAN -Part 54. TREMATODES OF FISHES, XIII-. PUBLICATIONS OF THE SETO MARINE BIOLOGICAL LABORATORY 1959, $7(2): 241-262$

ISSUE DATE:

1959-05-30

URL:

http://hdl.handle.net/2433/174607

RIGHT: 


\title{
STUDIES ON THE HELMINTH FAUNA OF JAPAN
}

\section{Part 54. TREMATODES OF FISHES, XIII}

\author{
SATYU YAMAGUTI \\ Department of Parasitology, Okayama University \\ Medical School, Okayama
}

With Plates $X X-X X I$

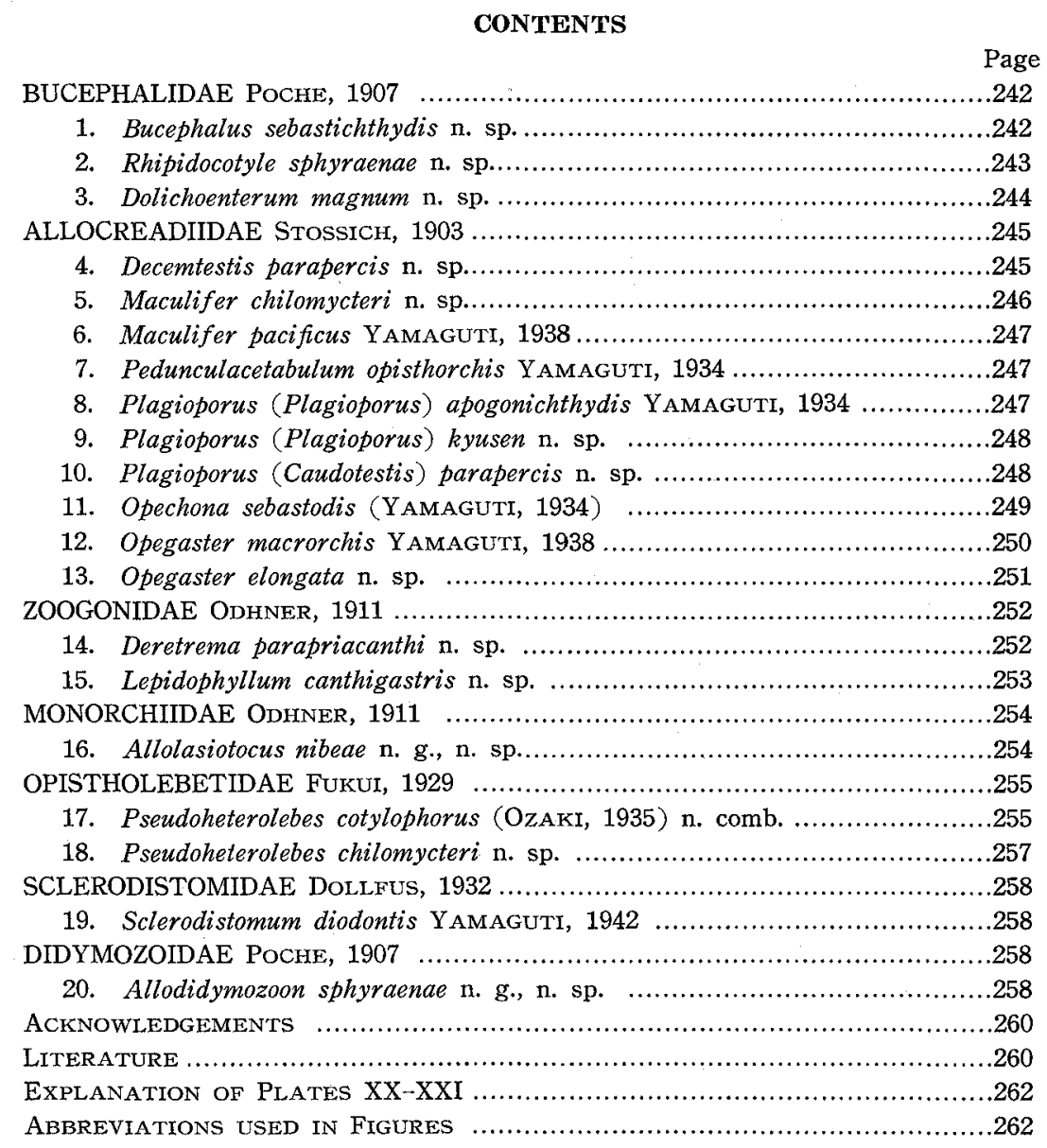

Publ. Seto Mar. Biol. Lab., VII (2), 1959. (Article 12) 


\section{BucephaldDae Poche, 1907}

\section{Bucephalus sebastichthydis n. sp.}

(Pl. XX, Fig. 1)

Habitat: Small intestine of Sebastichthys pachycephalus Temm. et ScHLEG.

Material, locality and date: A single gravid specimen fixed in Schaudinn's solution under a cover slip; Enoshima Aquarium; June 5, 1958.

Body cylindrical, $3.45 \mathrm{~mm}$ long by $0.44 \mathrm{~mm}$ broad, covered all over with minute scale-like spines; subcuticular muscle well developed in forebody. Rhynchus 0.34 $\times 0.32 \mathrm{~mm}$, consisting of coarse muscle bundles running perpendicularly to the surface of the organ and longer stouter bundles directed forward divergently from the base, provided along its anterior margin with a half-crown of seven, bifurcate, conical, horn-like processes $65-80 \mu$ long by $40 \mu$ broad at base. The above mentioned muscle bundles of the rhynchus do not extend into these horn-like processes. Mouth opening about midregion of body, pharynx $80 \times 90 \mu$; intestine turning back on itself a short distance anterior to pharynx and then descending to level of ovary.

Testes subglobular to oval, situated a little obliquely one behind the other in anterior part of caudal third of body; the anterior $0.21 \times 0.16 \mathrm{~mm}$, lying on the right a little behind ovary and the posterior $0.18 \times 0.17 \mathrm{~mm}$, at base of cirrus pouch; two vasa efferentia uniting together at level of anterior end of posterior testis. Cirrus pouch subcylindrical, $0.5 \times 0.11 \mathrm{~mm}$, provided with a coat of strong longitudinal muscle bundles; seminal vesicle elongate saccular, about $0.13 \mathrm{~mm}$ long, $52 \mu$ broad; pars prostatica about $0.39 \mathrm{~mm}$ long, prostate cells filling up all available space of cirrus pouch. The genital lobe, through which the ejaculatory duct passes, is crooked to the right, with its concavity directed toward the uterine opening. Genital atrium funnelshaped, about $0.1 \mathrm{~mm}$ in diameter, opening ventrally at a distance of $0.11 \mathrm{~mm}$ from rounded posterior end of body.

Ovary $0.19 \times 0.13 \mathrm{~mm}$, situated on the right a little posterior to pharynx. The germiduct arising from the dorsal side of the ovary forms near its origin a bulbous swelling $32 \mu$ wide, and then gives off the Laurer's canal at the point where it turns abruptly to the right. After joining the common vitelline duct it is surrounded by shell gland cells behind the ovary and thrown into convolutions, the proximal part of which contains abundant spermatozoa. Uterine coils reaching forward a little beyond anterior limit of vitellaria, occupying most of space between this level and posterior extremity, and opening into genital atrium opposite concavity of genital lobe; eggs oval, 23-26×13-16 $\mu$. Anterior vitelline follicles extending along each lateral margin of body, commencing at about junction of anterior with middle third of body; posterior follicles of each side tending to approach median line; right ones 13 in number, terminating medial to ovary; left ones 20 in number, reaching to near posterior testis ; right descending duct and left ascending duct unites with each other at level of 
anterior end of anterior testis. Excretory vesicle wide, tubular, extending into anterior third of body; pore terminal.

This species, characterized by the seven bifurcate tentacular processes of the rhynchus, bears a certain resemblance to Bucephalus aoria VERMA, 1936, or B. tridentacularia Verma, 1936, but differs from either of them in the relative position of the digestive and reproductive organs. In the latter respect as well as in general body shape it resembles $B$. scorpaenae MANTER, 1940, only differing in the character of the tentacular processes and the posterior extent of the vitellaria.

\section{Rhipidocotyle sphyraenae n. sp.}

(Pl. XX, Figs. 3-4)

Habitat: Small intestine of Sphyraena pinguis GüNTHER.

Material, locality and date: 8 gravid specimens; Sagami Bay; June 7, 1958.

Body subcylindrical, $0.9-1.7 \times 0.16-0.26 \mathrm{~mm}$, covered all over with minute scalelike spines. Rhynchus bowl-shaped, $0.07-0.11 \mathrm{~mm}$ long by $0.095-0.14 \mathrm{~mm}$ broad, with comparatively thin-walled muscular base and a semicircular apical hood, which is provided along its convex margin with a row of seven double papillae at nearly equal intervals and terminates on each side in an inwardly directed blunt point. Pharynx $46-52 \mu$ in diameter, just pre-equatorial. Intestine elongated saccular, terminating at level of anterior part of ovary.

Testes oval, tandem, postequatorial, to right of median line, $0.08-0.16 \times 0.06$ $0.12 \mathrm{~mm}$; posterior testis on the right of base of cirrus pouch. Cirrus pouch subcylindrical, $0.23-0.35 \times 0.04-0.06 \mathrm{~mm}$, extending on the left nearly whole length of caudal third of body, its wall consisting of longitudinal muscle bundles; seminal vesicle oval, at base of cirrus pouch; prostatic complex occupying greater part of cirrus pouch; ductus ejaculatorius strongly muscular, winding at distal end of cirrus pouch, may be everted into genital atrium in form of a stout cirrus when the cirrus is protruded; the reduced genital lobe is seen at the base of the cirrus. Genital pore ventral, with thick cuticular lining, $50-80 \mu$ from posterior tip of body.

Ovary subglobular, $0.07-0.12 \times 0.05-0.1 \mathrm{~mm}$, postequatorial, on the right immediately in front of anterior testis. Uterine coils ascending far forward to near rhynchus; eggs oval, $18-21 \times 13-14 \mu$. Vitelline follicles lateral, numbering about 10 on the right, but more numerous on the left; right follicles terminating at level of pharynx, left posterior follicles dorsal to uterus, extending as far backward as anterior testis. Excretory vesicle long, tubular, wide, reaching to near anterior end of uterus; pore terminal.

This species differs from the most closely related $R$. barracudae MANTER, 1940, from Sphyraena barracuda in the apical hood of the rhynchus being provided with seven marginal double papillae. In $R$. barracudae the apical hood is pentagonal, and apparently devoid of papillae. 


\section{Dolichoenterum magnum n. sp.}

(Pl. XX, Fig. 2)

Habitat: Small intestine of Conger conger LINNé.

Material: Three gravid specimens fixed under cover glass pressure, stained and mounted as usual, $16-20 \times 1.4-2.0 \mathrm{~mm}$.

Locality and date: Shinmaiko, Aquarium of Tokyo University; May 13, 1958.

Body elongate, more or less attenuated in region between mouth and anterior end of uterus, truncate in front and blunt-pointed behind. Cuticle densely beset all over with scale-like spines. In addition to the longitudinal subcuticular musculature which extends throughout the body, there are diagonal muscle fibers which are particularly well developed in the region between the rhynchus and the mouth opening. Rhynchus terminal, with wide ventral opening and a dorsal half-crown of 8 bluntconical muscular protuberances, $0.7-1.0 \times 0.9-1.1 \mathrm{~mm}$. Mouth opening midventrally at a distance of $2.7-4.0 \mathrm{~mm}$ from anterior extremity, leading into pharynx by way of a vestibule. Pharynx muscular, $0.3-0.35 \times 0.37-0.4 \mathrm{~mm}$; intestine at first ascending a short distance, then turning back on itself to descend in the median field to near middle of body where it is shifted dorsolaterad by the uterus and terminates short of the anterior testis.

Testes rounded, wide apart in posterior third of body, the anterior $(0.8 \times 0.7-1.0 \mathrm{~mm})$ on the right at about anterior end of posterior third of body, the posterior $(0.6-0.9$ $\times 0.85-1.2 \mathrm{~mm}$ ) slightly to left of median line in front of base of cirrus pouch. Cirrus pouch fusiform, strongly muscular, $1.5-1.7 \times 0.5 \mathrm{~mm}$, at posterior extremity. Seminal vesicle large, oval, $0.6-0.7 \times 0.36-0.4 \mathrm{~mm}$, at base of cirrus pouch; prostatic complex occupying rest of cirrus pouch. A large genital lobe projecting into genital atrium, which opens midventrally at the posterior end of the body.

Ovary rounded, $0.5-0.75 \times 0.6-0.7 \mathrm{~mm}$, situated behind anterior testis, from which it is separated by a uterine coil. Shell gland complex immediately postovarian. Uterus thrown into very close transverse coils, reaching to midregion of body, where it turns backward and occupies all available space between other genital organs and body wall, finally it runs down alongside the cirrus pouch and opens into the genital atrium; eggs elliptical, $18-20 \times 11-13 \mu$. Vitelline follicles extend along each side of body at irregular intervals; right ones $20-22$ in number, from equatorial zone to level of posterior testis; left ones 14-17 in number, less extensive than right ones, terminating at level of ovary or shell gland. Excretory vesicle tubular, wide, reaching to midregion of body, slightly beyond anterior end of uterus; pore dorsoterminal.

This species is characterized by its enormous size, to which the specific name refers. It differs from $D$. longissimum OzAKI, 1924, from the related fish host, in the posterior extent of the cecum and in the much smaller size of the eggs, in addition to the difference in body size. The description by TendeIro of Dolichoenterum manteri from a Portuguese conger eel was not available. 


\section{Allocreadiddae Stossich, 1903}

\section{Decemtestis parapercis n. sp.}

(Pl. XX, Fig. 6)

Habitat: Small intestine of Parapercis pulchella Temm. et Schleg.

Material: Two gravid specimens fixed in Schaudinn's solution under a cover slip and stained with Heidenhain's hematoxylin.

Locality and date: Ise Bay; May 12, 1958.

Body spatulate, broadly rounded or truncate behind, $2.7-2.8 \mathrm{~mm}$ in length, with maximum width of $0.83-1.25 \mathrm{~mm}$ behind middle. Cuticle thin, unarmed. Oral sucker subterminal, $0.22-0.23 \times 0.23-0.24 \mathrm{~mm}$, prepharynx distinct; pharynx subglobular to subcylindrical, $0.1-0.12 \times 0.12-0.15 \mathrm{~mm}$; esophagus $70 \mu$ long; ceca terminating at posterior extremity. Acetabulum $0.31-0.35 \times 0.33-0.38 \mathrm{~mm}$, situated at anterior part of middle third of body.

Testes subglobular or irregular in shape, $0.14-0.17 \times 0.17-0.3 \mathrm{~mm}$, six on right side of median line in the type. In the syntype, however, there are four on the right in a longitudinal row, and five on the left in a zigzag row. Cirrus pouch tubular, 1.0-1.15 $\times 0.08-0.11 \mathrm{~mm}$, extending a short distance back of acetabulum just beyond equatorial level; seminal vesicle tubular, twisted or sigmoid, with maximum width of $85 \mu$ at base, with its narrow distal portion convoluted. Pars prostatica apparently not differentiated; cirrus with corrugated surface. Genital pore sinistral to esophagus.

Ovary irregularly lobed, $0.27-0.3 \times 0.3-0.32 \mathrm{~mm}$, situated just medial to right cecum between acetabulum and right anteriormost testis. Seminal receptacle retort-shaped, 0.07-0.11 mm wide at base, immediately posterodorsal to ovary. The germiduct arising from the dorsal surface of the ovary joins the seminal receptacle at its attenuated distal end and then turns backward to receive the vitelline duct from the vitelline reservoir lying immediately behind the origin of the Laurer's canal. The Laurer's canal, originating from the distal end of the seminal receptacle just opposite the point of junction of the germiduct with the seminal receptacle, runs transversely to the left dorsal to the uterus and opens dorsally just behind the posterior end of the cirrus pouch. Uterine coils intruding into space between anterior testes and occupying whole space bounded by left anteriormost testis, ovary and acetabulum, then ascending on left side of cirrus pouch; metraterm well differentiated, muscular. Eggs oval, thinshelled, 54-62 $\times 33-39 \mu$. Vitellaria extending in lateral fields from level of pharynx to posterior extremity, confluent across esophagus and behind intestinal bifurcation, but separated behind testes by excretory vesicle; vitelline reservoir dorsal to left lobe of ovary in the type, but more medial in the syntype. Excretory vesicle tubular, with ventroterminal pore; it cannot be followed to its anterior end owing to excessive development of the uterus.

This species resembles D. callionymi YamaGuTI, 1934, in general anatomy, especially in the long cirrus pouch and in the intertesticular extent of the uterus, but differs from it in the vitellaria not being interrupted at the acetabular level. 


\section{Maculifer chilomycteri $\mathrm{n}$. sp.}

(Pl. XXI, Fig. 11)

Habitat: Small intestine (lower part) of Chilomycterus affinis GüNTHER.

Material: One gravid specimen and one senile specimen, both fixed in Schaudinn's solution under a cover slip, $3.9-4.7 \times 2.6-3.3 \mathrm{~mm}$.

Locality and date: Aquarium of Seto Marine Biological Laboratory, Shirahama; April 5, 1958.

Body flattened oval, blunt-pointed in front, rounded behind, with or without median posterior notch. In the type a pair of flat conical cuticular protuberances is seen at the posterior extremity, but in the senile specimen two similar protuberances are seen on either side of the median notch. Oral sucker cuboidal, $0.4-0.52 \times 0.52-0.6 \mathrm{~mm}$, surmounted by preoral lobe containing glandular tissue. In the type a pair of gland ducts about $0.1 \mathrm{~mm}$ apart from each other is seen opening on this preoral lobe. Postoral ring consisting exclusively of transverse muscle fibers enclosing posterior end of oral sucker as well as anterior part of prepharynx, from which it is separated by a considerable free space. Prepharynx $0.25-0.3 \mathrm{~mm}$ long by $0.4-0.55 \mathrm{~mm}$ wide, pharynx ring-shaped, $0.32-0.45 \times 0.6-0.78 \mathrm{~mm}$, esophagus short and wide, $0.1 \times 0.42 \mathrm{~mm}$ in the type, bifurcating at junction of anterior with middle third of body. Ceca wide, simple, terminating close to each other at posterior extremity. Acetabulum $0.67-0.83 \times 0.78-$ $1.0 \mathrm{~mm}$, embedded in body parenchyma at junction of middle with posterior third of body.

Testes oval, $0.34-0.4 \times 0.5-0.6 \mathrm{~mm}$, situated subsymmetrically at about middle of postacetabular region with their long axes oblique to body axis, each pressed against inner side of cecum of its own side. Cirrus pouch approximately fusiform, 0.7-0.75 $\times 0.16-0.17 \mathrm{~mm}$, tapered posteriorly, situated obliquely a little in front of acetabulum, containing tubular $\mathrm{N}$-shaped seminal vesicle, poorly differentiated cylindrical pars prostatica $(0.13 \mathrm{~mm}$ long by $30 \mu$ wide in the type) surrounded by clear prostatic cells and a narrow ductus ejaculatorius lined with thick smooth cuticle. Genital pore opening midventrally at intestinal bifurcation at base of a circular pit.

Ovary subglobular, $0.16-0.23 \times 0.26-0.3 \mathrm{~mm}$, in direct contact with right testis on its anteromedial surface. The germiduct arising from the anteromedial side of the ovary forms a bulbous swelling before turning back on itself and after joining the seminal receptacle proceeds forward to unite with the duct from the vitelline reservoir behind the posterior end of the acetabulum, where the shell gland cells are massed together. Seminal receptacle elongate, directly anteromedial to ovary ; its inner posterior end tapers to the Laurer's canal which turns back itself and runs obliquely forward crossing the germiduct dorsally, and opens dorsally a little in front of ovary. The proximal descending portion of the uterus passes between the two testes and turning back on itself follows an ascending course between the ovary and the acetabulum and then along the right border of the acetabulum, and finally alongside the 
cirrus pouch on its left side. The uterus proper contains two or more rows of eggs, but the narrower metraterm a single row; egg oval to elliptical, $68-91 \times 46-56 \mu$. Vitellaria surrounding ceca on all sides, commencing on the right at level of prepharynx but on the left at level of pharynx, meeting in median line both dorsally and ventrally at intestinal bifurcation and on dorsal side of hindbody; vitelline reservoir rounded, comparatively small, anterosinistral to ovary.

Excretory vesicle elongate saccular, reaching to dextrodorsal side of acetabulum; pore terminal.

\section{Maculifer pacificus YAMAGUTI, 1938}

A single gravid specimen was found in the gall bladder of Spheroides pardalis from Sagami Bay. As pointed out in my original description this species is easily distinguished from Maculifer japonicus LAYMAN, 1930, by the eggs measuring 57-75 $\times 36-42 \mu$ as against $78-91 \times 42-51 \mu$. It is interesting to note that trematodes which are normally parasitic in the gastro-intestinal tract may occasionally be found in the gall bladder.

\section{Pedunculacetabulum opisthorchis YAMAGUTI, 1934}

As fixed in Schandinn's solution under a cover slip and stained with Heidenhain's hematoxylin the three gravid specimens from Hoplognathus fasciata from Sagami Bay gave the following measurements in $\mathrm{mm}$.

Body $2.7-0.5 \times 0.45-0.55$, oral sucker $0.12-0.21 \times 0.17-0.23$, pharynx $0.11-0.16 \times 0.11-$ 0.18 ; acetabulum $0.15-0.2$ in diameter; testes $0.47-0.6 \times 0.21-0.32$, cirrus pouch $0.55-0.7$ $\times 0.11-0.15$; ovary $0.11-0.18 \times 0.16-0.2$; eggs $0.056-0.062$ long.

\section{Plagioporus (Plagioporus) apogonichthydis YAMAGUTI, 1938}

Four gravid specimens of this species were found in the small intestine of Apogon semilineatus Temm. et Schleg. from Sagami Bay, June 6, 1958. As fixed in Schaudinn's solution under a cover glass, stained and mounted, they gave the following measurements.

Body $0.94-1.4 \times 0.45-0.55 \mathrm{~mm}$, oral sucker $0.1-0.13 \mathrm{~mm}$ in diameter, pharynx $40-50$ $\times 60-65 \mu$, esophagus $50-70 \mu$, acetabulum $0.2-0.3 \times 0.24-0.27 \mathrm{~mm}$, testes $0.09-0.16 \times 0.16-$ $0.26 \mathrm{~mm}$, cirrus pouch $0.25-0.27 \times 0.05-0.08 \mathrm{~mm}$, reaching to dorsal side of anterodextral part of acetabulum, ovary $0.09-0.1 \times 0.14-0.17 \mathrm{~mm}$, receptaculum seminis $50-60 \mu$ wide, eggs $53-55 \times 33-35 \mu$.

As compared with my original description of the species the present material probably shows the lowest limit of variation instead of representing a new species or subspecies, because of complete agreement in disposition of all organs and in egg size. The present host is also very closely related to the type host. 


\title{
9. Plagioporus (Plagioporus) kyusen n. sp.
}

\author{
(Pl. XX, Fig. 7)
}

Habitat: Small intestine of Halichoeres poecilopterus Temm. et Schleg.

Material: Six, mostly macerated, gravid specimens fixed in Schaudinn's solution and stained with Heidenhain's hematoxylin.

Locality and date: Aquarium of Tokyo University at Shinmaiko on Ise Bay.

Body approximately fusiform, more tapered anteriorly than posteriorly, $0.65-0.9 \mathrm{~mm}$ in length, with maximum breadth of $0.22-0.3 \mathrm{~mm}$ behind middle. Cuticle thin and smooth. Oral sucker subterminal, $24-32 \mu$ in diameter, followed by distinct prepharynx ; pharynx 14-17 $\times 14-19 \mu$, esophagus $26-52 \mu$ long; ceca terminating near posterior extremity. Acetabulum $0.12-0.18 \mathrm{~mm}$ in diameter, nearly equatorial.

Testes subglobular, $56-104 \times 56-130 \mu$, obliquely tandem in posterior third of body, the anterior on the left, the posterior a little to the right. Cirrus pouch subcylindrical, $0.2-0.34 \mathrm{~mm}$ long, $46 \mu$ wide at posterior swelling, extending from dorsal side of anterior part of acetabulum to genital pore, containing winding tubular seminal vesicle, poorly differentiated pars prostatica, prostate cells and straight ejaculatory duct. Genital pore sinistral to intestinal bifurcation.

Ovary transversely elongated oval, $31-44 \times 44-56 \mu$, situated on the right just in front of posterior testis. Seminal receptacle spherical, $36 \times 44 \mu$ in the ty pe, immediately anterodorsal to ovary. The germiduct arising from the right end of the ovary joins the seminal receptacle at its posterior end, whence it turns forward across the seminal receptacle and then receives the duct from the vitelline reservoir. Laurer's canal is unable to trace to its dorsal opening.

Uterus distended with large eggs in the area bounded by anterior testis, shell gland, acetabulum and left cecum; metraterm well differentiated; eggs oval, very large as compared with body size, measuring $59-67 \times 36-40 \mu$. Vitelline follicles co-extensive with ceca, commencing at level of genital pore, not confluent in posttesticular area; vitelline reservoir triangular, anterosinistral to ovary. Excretory vesicle tubular, reaching to level of ovary; pore terminal.

This species is characterized by small body size and comparatively large egg size. The specific name is the Japanese name for the host.

\section{Plagioporus (Caudotestis) parapercis n. sp.}

$$
\text { (Pl. XX, Fig. 5) }
$$

Habitat: Small intestine of Parapercis pulchella.

Material: Four gravid specimens fixed in Schaudinn's solution under cover glass pressure, stained and mounted as usual.

Locality and date: Aquarium of Tokyo University at Shinmaiko; May 12, 1958.

Body flattened fusiform, with blunt-pointed extremities, $1.4-2.0 \mathrm{~mm}$ in length with 
maximum width of $0.55-0.9 \mathrm{~mm}$ at midregion. Cuticle thin and smooth. Oral sucker ventroterminal, $0.1-0.14 \times 0.11-0.17 \mathrm{~mm}$; prepharynx distinct, pharynx $0.04-0.1 \times 0.06-$ $0.11 \mathrm{~mm}$, esophagus $0.1-0.14 \mathrm{~mm}$ long. Ceca terminating one on each side of posterior testis. Acetabulum $0.19-0.3 \times 0.24-0.34 \mathrm{~mm}$, a little anterior to middle of body.

Testes subglobular to ovoid, $0.1-0.3 \times 0.15-0.44 \mathrm{~mm}$, slightly obliquely tandem at about middle of posterior half of body. Vasa efferentia penetrating base of cirrus pouch separately. Cirrus pouch subcylindrical to claviform, $0.2-0.35 \times 0.05-0.08 \mathrm{~mm}$; with well developed longitudinal musculature, reaching to acetabulum or not; seminal vesicle tubular, winding at swollen basal portion of cirrus pouch, with its distal end sharply constricted off from pars prostatica; latter subcylindrical, about $20 \mu$ wide in the type, leading imperceptibly into ductus ejaculatorius. Genital pore sinistral to esophagus.

Ovary $0.12-0.25 \mathrm{~mm}$ in diameter, divided into three or more rounded lobes, situated anterodextral to anterior testis, just postequatorial. The germiduct, arising dorsally from the center of the ovary, describes an $\mathrm{N}$-shaped loop, and at its second turn joins the seminal receptacle and Laurer's canal; the seminal receptacle is constricted into two parts, both being ciliated and containing yolk granules, and lies posterosinistral to the ovary; the Laurer's canal, running dorsal to the uterus, opens outside on the left of the median line about midway between the anterior testis and the acetabulum. Sigmoid uterine coils occupying most of space bounded by ovary, anterior testis and acetabulum and ascending sinistrodorsal to acetabulum and then alongside cirrus pouch; metraterm somewhat muscular; eggs oval, thin-shelled, 56-68 $\times 39-52 \mu$. Vitelline follicles compratively large, extending in lateral fields from level of esophagus or pharynx to posterior extremity, confluent across esophagus and intestinal bifurcation; vitelline reservoir immediately in front of anterior testis to left of ovary. Excretory stem may or may not reach to dorsal side of posterior testis; pore terminal.

This species differs from the most closely related Plagioporus (Caudotestis) sinitsini MuELler, 1934, in the host species as well as in the size and shape of the eggs. In $P$. sinitsini the host is a freshwater fish, and the eggs are ellipsoidal, measuring $70 \mu$ by $35 \mu$.

\section{Opechona sebastodis (YAMAGUTI, 1934)}

The following redescription is based on 15 gravid specimens from Sebastodes giintheri from the Inland Sea, and 7 specimens from Sebastodes schlegelii from Sagami Bay. They were fixed in Schaudinn's solution under cover glass pressure, stained with iron-hematoxylin and mounted in balsam as usual.

Body rather slender, more tapered anteriorly than posteriorly, 3.6-6.6 in length, $0.36-0.65 \mathrm{~mm}$ in maximum width at level of ovario-testicular region, covered all over with small scale-like spines. Oral sucker ventroterminal, $40-90 \times 52-106 \mu$, more or less drawn out posteriorly. Prepharynx $0.05-0.3 \mathrm{~mm}$ long, with dissociated ocular pigment granules on each side. Pharynx barrel-shaped, 50-106 $\times 36-80 \mu$. Esophagus narrow, 
0.4-2.0 mm long, bifurcating slightly in front of acetabulum; ceca simple, terminating at posterior extremity. Acetabulum $0.1-0.14 \mathrm{~mm}$ in diameter, situated in second sixth of body.

Testes rounded, $0.23-0.55 \times 0.18-0.42 \mathrm{~mm}$, situated one behind the other in the intercecal field; anterior testis at posterior end of middle third of body, posterior one at anterior part of posterior third of body. Vesicula seminalis externa tubular, twisted at posterior end of anterior third of body, elongate saccular when distended. Cirrus pouch claviform, $0.26-0.7 \times 0.05-0.1 \mathrm{~mm}$, with muscular wall, extending for most part posterior to acetabulum. Vesicula seminalis interna oval, $65-104 \times 50-80 \mu$; pars prostatica strongly developed, oval to cuboidal, $52-85 \times 65-83 \mu$; ductus ejaculatorius muscular, lined with thick cuticle, more or less winding. Genital pore immediately anterosinistral to acetabulum.

Ovary rounded or trilobate, $0.15-0.27 \times 0.16-0.3 \mathrm{~mm}$, in front of anterior testis, from which it is separated by seminal receptacle, vitelline reservoir and some vitelline follicles intruding into the space. The germiduct arising from the dorsal side of the ovary forms a slight fusiform swelling and then joins the ascending duct from the seminal receptacle, and after turning back on itself unites with the vitelline duct ascending from the vitelline reservoir; ootype situated anterodorsal to ovary. Seminal receptacle oval to retort-shaped, situated posterodorsal to ovary and dorsal to vitelline reservoir. The Laurer's canal originating from the duct of the seminal receptacle just before the latter joins the germiduct, proceeds windingly or straight backward and opens dorsally in the left submedian line at the level of the seminal receptacle. Uterine coils occupying all available space of intercecal field between ovary and vesicula seminalis externa. Metraterm very strongly muscular, winding forward alongside cirrus pouch. As fixed in alcohol and measured in water the elliptical thin-shelled eggs are $65-78 \mu$ long by $45-50 \mu$ broad. Vitelline follicles surrounding ceca on all sides usually commencing at level of vesicula seminalis externa, occasionally a little more anteriorly or posteriorly, and terminating at posterior extremity, confluent in median line in inter- and posttesticular regions; some follicles approaching median line or confluent in the space between ovary and anterior testis; the anterior extent of the two preovarian lateral follicles is variable individually, and not always at the same level even in the same individual. Vitelline reservoir ventral to seminal receptacle behind ovary; the common vitelline duct, arising from the anterior or anterosinistral end of the reservoir, passes forward crossing the germiduct ventrally. Anterior extent of excretory vesicle unable to determine; pore terminal.

The minor differences in measurements between my original material of 1934 and the present one are due to the difference in technique employed.

\section{Opegaster macrorchis YAMAGUTI, 1938}

Habitat: Small intestine of Parapercis ommatura Jordan et SNyder. Locality and date: Inland Sea; May 12, 1958. 
Two gravid specimens fixed in Schaudinn's solution under cover glass pressure gave the following measurements.

Body $1.9-2.1 \times 0.57-0.64 \mathrm{~mm}$, oral sucker $0.12-0.13 \times 0.15-0.16 \mathrm{~mm}$, pharynx $0.09-0.1$ $\times 0.07-0.08 \mathrm{~mm}$, esophagus about $50 \mu \mathrm{long}$; anus about $75 \mu$ from posterior end of body ; acetabulum $0.26-0.28 \mathrm{~mm}$ in diameter, with three papillae on anterior and posterior free border respectively. Testes indented, directly tandem behind equator, $0.25-0.3 \times$ $0.42-0.46 \mathrm{~mm}$; seminal vesicle swollen at base to maximum width of $0.16 \mathrm{~mm}$, reaching to level of middle or posterior end of acetabulum; cirrus pouch $104 \times 40 \mu$; genital pore sinistral, level with esophagus. Ovary transversely elongate, $0.1-0.12 \times 0.3-0.31 \mathrm{~mm}$, slightly to right; Laurer's canal forming a loop before opening dorsal to ovary behind vitelline reservoir or immediately anterior to ovary to left of vitelline reservoir. Uterus coiled between ovary and acetabulum; metraterm well differentiated ; eggs $56-65 \times 39$ $42 \mu$. Vitellaria extending in lateral fields from level of genital pore to posterior extremity, confluent in posttesticular region; vitelline reservoir transversely elongated or triangular, anterodorsal to ovary. Excretory vesicle reaching to posterior end of ovary.

As compared with the original material of this species from Neopercis multifasciata, the pharynx is longer than broad and the esophagus is very short in the present material, but this difference is probably due to different state of contraction of these organs.

\section{Opegaster elongata n. sp.}

(P1. XXI, Fig. 10)

Habitat: Small intestine of Apogon semilineatus TEMm. et ScHLEG.

Material: A single gravid specimen fixed in Schaudinn's solution, stained and mounted.

Locality and date: Sagami Bay; June 6, 1958.

Body elongate, $1.8 \mathrm{~mm}$ long, $0.42 \mathrm{~mm}$ broad at level of acetabulum ; forebody abruptly tapered, but hindbody gradually tapered, both with blunt extremities, scattered all over with cuticular papillae as in Opegaster apogonichthydis YAMAGUTI, 1938. Cervical glands well developed. Oral sucker subterminal, $0.11 \times 0.145 \mathrm{~mm}$, followed by very short prepharynx; pharynx $0.05 \times 0.055 \mathrm{~mm}$, esophagus $40 \mu$ long. Ceca uniting posteriorly; anus ventral, about $85 \mu$ from posterior tip of body. Acetabulum protuberant, $0.21 \mathrm{~mm}$ in diameter, situated at posterior half of anterior third of body, with 6 horn-like projections, three on anterior margin and three on posterior margin.

Testes directly tandem, at posterior half of middle third of body, occupying whole breadth of intercecal field; anterior testis reniform, $0.14 \times 0.2 \mathrm{~mm}$, posterior testis flattened in front, $0.15 \times 0.18 \mathrm{~mm}$. Vesicula seminalis tubular, extending from immediately behind acetabulum into cirrus pouch, describing three turns in front of acetabulum; cirrus pouch $34 \mu$ in diameter, enclosing distal end of seminal vesicle, rounded pars prostatica surrounded by prostatic ducts coming from outside cirrus pouch, and ejaculatory 
duct, extending from ventral side of left cecum to genital pore. Genital pore just left of intestinal bifurcation.

Ovary reniform, $0.11 \times 0.18 \mathrm{~mm}$, a little to right immediately in front of anterior testis, nearly equatorial. The germiduct arising from the depth of the concavity of ovary proceeds obliquely forward ventral to the vitelline reservoir, at the anterior end of which it gives off the Laurer's canal, and after turning back on itself receives the duct from the vitelline reservoir. The Laurer's canal forming a loop immediately anterodextral to the vitelline reservoir runs obliquely along this reservoir and finally after describing another loop opens dorsally in front of the left lobe of the ovary. Uterine coils occupying whole intercecal field between ovary and acetabulum; metraterm well differentiated, running forward alongside seminal vesicle, crossing over cirrus pouch ventrally. Eggs oval, thin-shelled, 50-60×33-36 $\mu$. Vitelline follicles extending mostly in extracecal fields, but in posttesticular region they are almost confluent in the median line. On the right side they commence at the level of the anterior end of the acetabulum, but a little more posteriorly on the left. Excretory vesicle reaching to posterior end of ovary; pore terminal.

This species differs from the most closely related $O$. apogonichthydis YamaGUTI, 1938 , in the anterior extent of the vitellaria and smaller egg size, and from $O$. pentadactyla MANTER, 1940, in the marginal tentacular projections of the acetabulum and egg size. In MANTER's species constant "rudimentary vitellaria" are seen in the forebody and the eggs are 46 to $50 \mu$ by 26 to $29 \mu$.

\section{ZOOGONIDAE ODHNER, 1911}

\section{Deretrema parapriacanthi n. sp.}

$$
\text { (PI. XXI, Fig. 9) }
$$

Habitat: Small intestine of Parapriacanthus beryciformes Franz.

Material: Two gravid specimens fixed in Schaudinn's solution under cover glass pressure and stained with Heidenhain's hematoxylin.

Locality and date: Sagami Bay; June 6, 1958.

Body elliptical or oblong, with blunt-pointed extremites, $2.1-2.75 \mathrm{~mm}$ long by $0.75-1.0 \mathrm{~mm}$ broad. Cuticle may be transversely striated, unspined. Oral sucker subterminal, $0.16 \mathrm{~mm}$ in diameter, pharynx $41 \times 52 \mu$, esophagus $0.1-0.16 \mathrm{~mm}$ long ; posterior cecal extent not made out. Acetabulum $0.24-0.26 \mathrm{~mm}$ in diameter, just pre-equatorial.

Testes subglobular, $0.16-0.2 \mathrm{~mm}$ in diameter, situated symmetrically at posterior end of middle third of body. Cirrus pouch claviform, $0.22-0.26 \times 0.056-0.06 \mathrm{~mm}$, extending transversely from ventral side of left cecum to left margin of body immediately behind level of intestinal bifurcation, containing tubular seminal vesicle, prostatic complex and ejaculatory duct. Genital pore postbifurcal, on slightly notched left edge of body.

Ovary subglobular, wider than long, $0.21 \times 0.33 \mathrm{~mm}$ in the type, overlapping aceta- 
bulum on its posterodextral border, with transversely elongated seminal receptacle immediately behind. Uterus occupying all available space posterior to intestinal bifurcation, ventral to ovary, testes and dorsal vitelline follicles; metraterm anterodorsal to cirrus pouch; eggs elliptical, thick-shelled, $44-52 \times 23-29 \mu$. Vitelline follicles $8-9$ on each side, forming symmetrical lateral clusters between cirrus pouch and equator, a few follicles dorsal to uterus; vitelline reservoir small, behind medial end of ovary. Excretory arms terminating one on each side of esophagus; excretory pore terminal.

This species resembles $D$. pooli AnNereaux, 1947, more closely than any other members of the genus not only in general body shape but also in the internal anatomy, but differs distinctly in egg size. In $D$. pooli the eggs are $50-60 \mu$ by $30-32 \mu$.

\section{Lepidophyllum canthigastris sp.}

(Pl. XXI, Fig. 12)

Habitat: Urinary bladder of Canthigaster rivulata (Temm. et Schleg.)

Material: Two gravid specimens fixed in Schaudinn's solution under a cover slip and stained with Heidenhain's hematoxylin.

Locality and date: Sagami Bay; June 7, 1958.

Body leaflike, $1.5-2.0 \mathrm{~mm}$ long, tapered anteriorly and remarkably expanded at hindbody, with a median or submedian notch at posterior extremity. Cuticle thin and smooth. Oral sucker subterminal, $0.11-0.14 \times 0.11-0.17 \mathrm{~mm}$; short prepharynx present ; pharynx globular, 70-90 $\mu$ in diameter; esophagus $90 \mu$ long; ceca with irregular outline, especially posteriorly, and terminating in anterior part of posterior half of body just medial to vitellaria, distended with amorphous ingesta containing dark pigment granules. Acetabulum $0.2-0.32 \times 0.19-0.3 \mathrm{~mm}$, just pre-equatorial.

Testes deeply lobed, especially on outer side, $0.24-0.3 \times 0.12-0.25 \mathrm{~mm}$, situated symmetrically at junction of middle with posterior third of body, immediately behind vitellaria. Vas efferens arising from dorsal side of anterior part of each testis unites with its fellow on ventral side of anterior end of ovary; vas deferens running straight forward dorsal to acetabulum. Cirrus pouch cylindrical, $0.4-0.45 \times 0.035-0.04 \mathrm{~mm}$, extending obliquely from in front of acetabulum toward left margin of body, containing seminal vesicle, prostatic complex and ductus ejaculatorius, the distal end of which is seen everted in both specimens. Genital pore close to left body margin at level of posterior end of pharynx.

Ovary lemon-shaped, $0.08-0.1 \times 0.1-0.12 \mathrm{~mm}$, median, postacetabular, between two cecal ends. The germiduct originating from the ventral side of the ovary proceeds backward and becomes slightly expanded at the point where the Laurer's canal is given off, and then unites with the common vitelline duct coming from behind. Uterus convoluted in inter- and posttesticular region; metraterm running along cirrus pouch on its medial side and opening outside just in front of cirrus. Eggs elliptical, 26-44 $\times 15-25 \mu$. Vitellaria forming symmetrical bunches of about 10 follicles each just 
lateral to cecal ends; vitelline ducts joining together behind ovary; unpaired vitelline duct hook-shaped, with its distal end turned back on itself. Excretory vesicle tubular, short; pore terminal.

This species differs from L. steenstrupi ODHNER, 1902, from the urinary bladder of Anarrhichas minor s. pantherinus from Iceland, in the smooth body, in the acetabulum being definitely larger than the oral sucker, in the anterior position of the genital pore, in the vitellaria being lateral to the ceca, in the seminal receptacle being greatly reduced, etc., and from $L$. armatum ZHukov, 1957, in the smooth cuticle, the sucker ratio and the position of the genital pore. In the latter two respects as well as in the position of the vitellaria relative to the ceca it differs also from $L$. brachycladium Zнuкоv, 1957, and L. pleuronectini Zнuкоv, 1957.

\section{MONORCHIIDAE ODHNER, 1911}

\section{Allolasiotocus nibeae n. g., n. sp.}

(P1. XX, Fig. 8)

Habitat: Small intestine of Nibea schlegeli (BleEker).

Material: 10 gravid specimens fixed in Schaudinn's solution under cover glass pressure, stained and mounted as usual.

Locality and date: Sagami Bay; June 6, 1958.

Body fusiform, with blunt-pointed extremities, $1.1-1.6 \mathrm{~mm}$ long by $0.55-0.75 \mathrm{~mm}$, $2.4 \times 1.0 \mathrm{~mm}$ in a strongly flattened syntype ${ }^{13}$, broadest at preacetabular level. Cuticle thin, beset all over with very fine scale-like spines. Oral sucker subterminal, 0.13-0.16 $\times 0.14-0.17 \mathrm{~mm}$; pharynx small, $45-65 \times 40-63 \mu$; esophagus $0.025-0.1 \mathrm{~mm}$ long; ceca terminating close to lateral margins at anterior end of caudal third of body. Acetabulum weakly muscular, $0.08-0.11 \mathrm{~mm}$ in diameter, situated at junction of anterior with middle third of body.

Testes single, subglobular, $0.18-0.25 \mathrm{~mm}$ in greater diameter, median, in middle third of body. Vesicula seminalis externa oval, $0.11-0.14 \mathrm{~mm}$ in diameter, overlapping ovary to right of median line. Cirrus pouch voluminous, $0.2-0.26 \times 0.14-0.16 \mathrm{~mm}$, situated transversely or obliquely immediately behind intestinal bifurcation, containing rounded internal seminal vesicle $0.11-0.14 \mathrm{~mm}$ in diameter and well developed prostatic complex ; the ejaculatory duct opens directly into the genital atrium which consists of three chambers covered inside with long bristles, and opens ventrally by a large round aperture slightly to left of median line nearly halfway between intestinal bifurcation and acetabulum.

It is interesting to note that the cirrus is represented by the widest right chamber of the genital atrium and the female terminal organ by the left chamber.

1) Measurements of internal organs in this specimen are not given owing to artificial exaggeration. 
Ovary irregularly indented or lobed, $0.15-0.17 \times 0.12-0.17 \mathrm{~mm}$, situated medial to right cecum just anterodextral to testis, the germiduct arising from the dorsal surface of the ovary forms a small bulbous dilatation near its origin and gives off Laurer's canal before joining the common vitelline duct. No seminal receptacle. Laurer's canal short, straight, opening almost middorsally behind acetabulum. Uterus strongly convoluted, occupying all available space of body behind cirrus pouch; metraterm represented by median posterior chamber of genital atrium; eggs oval, thick-shelled, 18-20 $\times 14-17 \mu$. Vitellaria forming symmetrical bunches of large follicles in shoulder region, 6-9 follicles on each side; paired vitelline ducts joining together close to dorsal cuticle medial to ovary. Excretory vesicle was unable to make out.

In general internal anatomy this genus agrees with Lasiotocus Looss, 1907, only differing in having an external seminal vesicle and in the cirrus being represented by the widest right chamber of the genital atrium.

\section{Allolasiotocus n. g.}

Generic diagnosis.-Monorchiidae: Body small fusiform, spinose. Oral sucker subterminal, pharynx small, esophagus short, ceca not reaching posterior extremity. Acetabulum weakly muscular, well apart from anterior extremity. Testes single, postacetabular. External seminal vesicle present. Cirrus pouch postbifurcal, enclosing large internal seminal vesicle and well developed prostatic complex. Genital atrium consisting of three (right left and median) chambers densely lined with long bristles, opening ventrally out of median line posterior to intestinal bifurcation; right chamber corresponding to cirrus, left chamber to female terminal organ, and median posterior chamber to metraterm. Genital pore wide, submedian, postbifurcal, preacetabular. Ovary dextral, at acetabular or postacetabular level. No seminal receptacle, Laurer's canal present. Uterus strongly convoluted and occupying most of body posterior to genital pore: eggs numerous, thick-shelled. Vitelline follicles massed in symmetrical bunches in shoulder region. Excretory vesicle? Parasitic in intestine of marine teleosts.

Genotype: A. nibeae n. sp.

\section{Opistholebetidae Fukui, 1929}

17. Pseudoheterolebes cotylophorus (OzAKI, 1935) n. comb.

Habitat: Small intestine of Chilomycterus affinis GÜNTHER.

Material: 9 gravid specimens fixed under cover glass pressure in Schaudinn's solution with acetic acid added.

Locality and date: Aquarium of Seto Marine Biological Laboratory, Shirahama; April 5, 1958.

The following measurements are somewhat exaggerated owing to cover glass pressure.

Body 2.1-2.8 $\mathrm{mm}$ long by $2.3-2.8 \mathrm{~mm}$ wide, prominent at anterior end, convex laterally, truncate and frilled or corrugated at posterior extremity. Oral sucker globular, $0.2-0.3 \times 0.3-0.42 \mathrm{~mm}$, followed by a ring of circular muscle fibers. Pharynx 
ring-shaped, $0.17-0.22 \times 0.26-0.38 \mathrm{~mm}$. Acetabulum $0.5-0.68 \times 0.56-0.73 \mathrm{~mm}$, postequatorial or posterior according to the technique employed; circumacetabular fold very conspicuous, with puckered margin. Testes $0.2-0.3 \times 0.27-0.38 \mathrm{~mm}$, symmetrical or subsymmetrical, usually overlapping acetabulum at different levels in different individuals. Exceptionally the two testes may overlap the acetabulum diagonally on its anterosinistral border, the anterior one being exactly opposite the ovary. Such a great individual variability in relative position of the testes and ovary is partly due to the cover glass pressure applied to the acetabulum, by which the testes may be pushed either backward or forward ; the ovarian complex, however, is not affected substantially and lies always anterior or anterodorsal to the acetabulum on the right of the median line. Cirrus pouch fusiform, $0.28-0.5 \times 0.08-0.125 \mathrm{~mm}$; seminal vesicle convoluted and occupying greater posterior part of cirrus pouch. A small pars prostatica is differentiated at the anterior end of the attenuated distal portion of the seminal vesicle; ductus ejaculatorius narrow and straight. Genital pore median, at intestinal bifurcation or immediately behind it.

Ovary bean-shaped, $0.16-0.2 \times 0.22-0.34 \mathrm{~mm}$, anterodorsal or anterior to acetabulum; seminal receptacle retort-shaped, immediately preovarian, $0.12-0.17 \mathrm{~mm}$ wide. Laurer's canal opening middorsally at level of ovary. Uterine coils confined to left intercecal area opposite ovary and cirrus pouch anterior to acetabulum or testes; receptaculum seminis uterinum may be conspicuous occasionally. Eggs ovoid, thin-shelled, 78-86 $\times 46-62 \mu$. Vitellaria extending in broad lateral fields from level of oral sucker or prepharynx to cecal ends, leaving median and postcecal fields free; some follicles may extend medially over the intestinal bifurcation.

Because of the presence of a conspicuous circumacetabular fold this species should be separated from Heterolebes species lacking this fold. Hence a new genus Pseudoheterolebes is proposed, with present species as type. In the type of Opistholebes (O. amplicoelus NicolL, 1915), O. elongatus OzAKI, 1937, and O. adcotylophorus MANTER, 1947, there is no circumacetabular fold.

\section{Pseudoheterolebes n. g.}

Generic diagnosis.-Heterolebetidae: Body discoid, truncate and frilled at posterior extremity. Oral sucker subterminal, with well developed postoral ring, prepharynx longer than esophagus, pharynx ring-shaped. Ceca arcuate, terminating near posterior extremity. Acetabulum postequatorial or posterior, surrounded by collar with puckered margin. Testes rounded or oval, symmetrical or subsymmetrical, more or less overlapping acetabulum; may be pre- or postacetabular. Cirrus pouch fusiform or claviform, containing convoluted seminal vesicle, small pars prostatica surrounded by prostatic cells and straight ejaculatory duct. Male genital pore opening midventrally alongside uterine pore or by a common aperture at intestinal bifurcation or immediately behind it. Ovary anterior cr anterodorsal to acetabulum on the right of median line. Seminal receptacle immediately preovarion. Laurer's canal present. Uterine coils pretesticular, opposite ovary and cirrus pouch; eggs moderately large, thin-shelled. Vitelline follicles circumcecal, commencing at level of oral sucker or pharynx. Excretory vesicle? Parasitic in intestine of marine teleosts. 
Genotpye: P. cotylophorus (OzAKI, 1935) n. comb., syn. Heterolebes cotylophorus OzAKI, 1935 Other species: $P$. chilomycteri n. sp.

\title{
18. Pseudoheterolebes chilomycteri n. sp.
}

\author{
(Pl. XXI, Fig. 13)
}

Habitat: Small intestine of Chilomycterus affinis GüNTHER.

Material: Two gravid specimens fixed in Schaudinn's solution under a cover slip, stained and mounted as usual, $2.6-3.0 \times 2.5-2.8 \mathrm{~mm}$.

Locality and date: Aquarium of Seto Marine Biological Laboratory, Shirahama; April 5, 1958.

Body discoid, more or less truncated and frilled or corrugated at posterior end, with median notch. Cuticle smooth. A pair of flat papillae at level of anterior end of oral sucker. The anterior extremity filled with sticky glands projects beyond the oral sucker in form of a flattened cone, at the apex of which there are three (a median and two lateral) openings of the gland ducts. A pair of dorsolateral gland ducts appears to open ventrally on the oral aperture. Oral sucker rounded rectangular, $0.22-0.3 \times 0.37-0.4 \mathrm{~mm}$, subterminal, surmounted by above mentioned glandular preoral lobe, followed by strongly developed postoral ring, which surrounds the prepharynx about $0.1 \mathrm{~mm}$ long. Pharynx ring-shaped, $0.2-0.23 \times 0.34-0.35 \mathrm{~mm}$. Esophagus very short; ceca wide, arcuate, terminating blindly at posterior extremity, wide apart from each other. Acetabulum $0.6-0.66 \mathrm{~mm}$ in diameter, situated just behind middle of body, provided with an irregular fold of cuticle which does not surround the acetabulum in a continuous circle, the postacetabular fold merging into the posterior frill of the body. On each side of the acetabulum there are strong radial muscle fibers attached to this sucker.

Testes oval, symmetrical, immediately postacetabular, with their long axes divergent, measuring $0.35-0.4 \times 0.27-0.3 \mathrm{~mm}$. Cirrus pouch claviform, $0.54-0.6 \times 0.12-0.14 \mathrm{~mm}$, with its base overlapping acetabulum; seminal vesicle tubular, convoluted, occupying greater swollen portion of cirrus pouch; pars prostatica not distinctly differentiated; ductus ejaculatorius straight and narrow, opening alongside metraterm in a shallow pit, $0.12 \mathrm{~mm}$ behind pharynx in the type.

Ovary oval, $0.26-0.3 \times 0.2 \mathrm{~mm}$, overlapping right testis on its mediodorsal side. The germiduct arising from near the middle of the anteromedial margin of the ovary becomes dilated and turns back on itself to join the seminal receptacle and then proceeds anteromesad to receive the vitelline duct dorsal to the posterosinistral margin of the acetabulum. Receptaculum seminis elongate, lying alongside ovary, joining germiduct on anterior surface near its proximal end, its tapering distal portion describing an S-shaped turn mediodorsal to left testis and continued into straight Laurer's canal, which opens outside dorsal to the dextroposterior margin of the acetabulum. After forming a loop dorsal to the left testis the uterus runs forward windingly on 
the left side of the acetabulum and cirrus pouch; metraterm with well developed circular muscle fibers, opening outside beside ejaculatory duct in a shallow pit. Eggs oval, 78-96 $\times 54-63 \mu$, with a knob close to its antiopercular pole. Vitelline follicles comparatively small, extending in lateral fields from beside oral sucker and pharynx to posttesticular area, almost confluent across median line dorsal to intestinal bifurcation. Excretory system not worked out.

This species resembles $P$. cotylophorus (OzAKr, 1935) in body shape but differs from it in the ovarian complex being situated behind the acetabulum between and dorsal to the testes. In $P$. cotylophorus the testes may lie symmetrically just behind the acetabulum, but even in this case the ovary is far anterior to the testes and never comes to lie between the latter.

\section{Sclerodistomidae Dollfus, 1932}

\section{Sclerodistomum diodontis YAMAGUTI, 1942}

11 gravid specimens of this species were found in the stomach of Diodon holoacanthus which died in the Aquarium of the Seto Marine Biological Laboratory, Kyoto University. As fixed in Schaudinn's solution under strong cover glass pressure, stained and mounted, they gave the following measurements in mm.

Body 6.6-10.3 $\times 2.8-4.5$; oral sucker $0.55-0.8 \times 0.67-1.0$; pharynx $0.2-0.35 \times 0.26-0.4$; acetabulum $1.2-2.0$ across; testes $0.35-0.55 \times 0.45-0.8$; genital cone $0.4-0.7 \times 0.13-0.2$; ovary $0.2-0.6 \times 0.4-0.7$; eggs $0.03-0.036 \times 0.021-0.026$.

\section{Didymozoidae Poche, 1907}

20. Allodidymozoon sphyraenae n. g., n. sp.

(PI. XXI, Figs. 14-15)

Habitat: Submucosa of palate of Sphyraena pinguis GüNTHER.

Material: 13 young and full-grown specimens, flattened under cover glass pressure after the eggs had been dissected out of the distended uterus in the grown-up specimens, fixed in Schaudinn's solution, stained with Delafield's hematoxylin except 4, which were stained with Heidenhain's hematoxylin.

Locality and date: Sagami Bay; June 7, 1958.

In the full-grown cysts the two individuals which are almost equal in size were seen spirally coiled together by their hindbodies with the forebodies tuckled in between, but in one cyst there were three individuals of different size; the cyst membrane is so thin and delicate that it can easily be overlooked.

Forebody slender, filiform, 0.7-0.9 mm long (unusually long in one specimen), with slight dilatation $(0.1-.013 \mathrm{~mm}$ wide) in esophageal region and very fine transverse striations, attached to hindbody near one end of hindbody where the testes are located. 
Hindbody spirally twisted, wtth rounded ends, $2.2-6.8 \mathrm{~mm}$ long, covered with thin smooth cuticle.

Mouth terminal, opening at tip of prominent apical cone; oral sucker elongate pyriform, $31-41 \times 18-23 \mu$, directly followed by subglobular pharynx $15-20 \mu$ in diameter. Esophagus very long and narrow, straight anteriorly but irregularly winding for the greater posterior part; ceca narrow and winding in forebody, but as they enter the hindbody they become gradually wider and finally terminate at the posterior extremity, where they are nearly half as wide as the body itself. No acetabulum.

Testes tubular, long, $0.25-1.0 \mathrm{~mm}$ long, situated parallel to each other near base of forebody in anterior part of hindbody, with their blunt ends directed anteriorly. Vas deferens distended with spermatozoa, ascending windingly dorsal to uterus, opening midventrally together with opening of metraterm.

Ovary divided near its proximal end into three slender tubular branches, of which two extend forward along the convex side of the hindbody, one reaching to near the anterior end of the hindbody but the other terminating almost half way up; the remaining backwardly directed branch gives off on the convex side a comparatively short convoluted branch near its origin, and then another branch a short way down, and finally terminates near the convex side of the posterior extremity; hence there are 5 terminal branches in all in the type specimen; in other specimens the number of the terminal ovarian branches was unable to determine. The sigmoid main trunk of the ovary, which lies near the convex side of the postequatorial region of the hindbody, gradually tapers as it proceeds toward the shell gland, in which the germiduct joins the common vitelline duct. There is neither seminal receptacle nor Laurer's canal. The narrow greater proximal portion of the uterus is confined to the peripheral area of the hindbody, while the wider distal portion distended with eggs occupies the central area ; before entering the forebody the uterus forms a very wide cylindrical reservoir lying in the central axis of the hindbody as in other didymozoids; at the base of the forebody, however, it tapers again into a winding tube running forward in the intercecal field of the forebody; after crossing the intestinal bifurcation it comes to lie ventral or ventrolateral to the esophagus; the terminal portion of the uterus is differentiated into a straight median duct which is lined with cuticular leaflets and tapers markedly before opening midventrally just behind the apical mouth aperture. Eggs bean-shaped, $13-16 \times 7-8 \mu$. The common vitelline duct, comparatively narrow (36 $\mu$ wide in the type) and sigmoid, is divided into two main trunks, of which the anterior is subdivided into four branches and the posterior into five branches; all the branches, extending along the convex side of the hindbody like the ovarian branches, terminate near the cuticle at different levels, the longest anterior branch reaches the anterior extremity and the four posterior branches terminate at the posterior extremity. Excretory system not worked out.

This species bears a certain resemblance to Didymozoon spirale YAMAGTr, 1938, from the submucosa of the buccal cavity of Platycephalus indicus, but differs from it fundamentally in the internal anatomy; in Didymozoon as well as in Didymocystis 
the shell gland complex lies at or near the level of the proximal ends of the testes, anterior to the midregion of the hindbody, whereas in the present genus it is far removed from the testes, and the seminal receptacle is absent contrary to Didymozoon and Didymocystis. Furthermore, the female reproductive organs do not extend into the testicular region in Didymozoon, to which the present genus is more related in general body shape than to any other genera.

\section{Allodidymozoon n. g.}

Generic diagnosis.-Didymozoidae: Encysted in pairs, with hindbodies coiled together and forebodies tuckled in between. Forebody slender, somewhat expanded in esophageal region, attached to hindbody near its anterior extremity; hindbody cylindrical, spirally twisted, with rounded ends. Oral sucker very prominent, pyriform, directly followed by pharynx; esophagus long, winding; ceca inflated in hindbody, especially at its posterior extremity. No acetabulum. Testes tubular, parallel to each other, in anterior part of hindbody. Vas deferens in forebody, apparently opening together with opening of metraterm. Ovary tubular, branched, extending near convex side of hindbody throughout its length; shell gland situated far back of testes near convex side; seminal receptacle absent. Vitellaria tubular, branched, extending near convex side of hindbody throughout its length. Greater proximal portion of uterus convoluted in peripheral area of hindbody, distal inflated portion occupying most of central area of hindbody, tapering as it enters forebody and running in median field of latter; metraterm lined with cuticular leaflets, opening midventrally very close to apical mouth aperture; eggs bean-shaped, small. Excretory vesicle? Parasitic in submucosa of buccal cavity of marine teleosts.

Genotype: A. sphyraenae n. sp.

\section{Acknowledgements}

I am greatly indebted to the Enoshima Aquarium ar Katase, Kanagawa Prefecture, the Seto Marine Biological Laboratory of Kyoto University, and Tamano Marine Laboratory of Okayama University for their generous supply of laboratory facilities and fish materials from which the parasites described here were collected.

\section{LITERATURE}

AnNereaux, R. F. 1947. Three new trematodes from marine fishes of California. Trans. Amer. Micr. Soc., 66 (3), 249-255.

Looss, A. 1907. Beiträge zur Systematik der Distomen (Zur Kenntnis der Familie Hemiuridae). Zool. Jahrb. (Syst.), 26 (1), 163-180.

MANTER, H. W. 1940. Digenetic trematodes of fishes from the Galapagos Islands and the neighboring Pacific. Allan Hancock Pacif. Exped., 2 (14), 325-497.

Mueller, J. F. 1934. Two new trematodes from Oneida Lake fishes. Trans. Amer. Micr. Soc., $53(3), 231-236$.

NicolL, W. 1915. The trematode parasites of North Queensland. III. Parasites of fishes. Parasit., $8(1), 22-41$.

ODHNER, T. 1902. Mitteilung zur Kenntnis der Distomen. Ctbl. Bakt., (I), 31, 58-68, $152-162$.

OzAKI, Y. 1935. Two new trematodes of the family Opistholebetidae Travassos. Proc. Imp. Acad. Tokyo., 11 (6), 244-246. 
OzAKI, Y. 1937. Studies on the trematode families Gyliauchenidae and Opistholebetidae, with special reference to lymph system. I. J. Sc. Hiroshima Univ. Ser. B, Div. 1, 5 (5), 125-165. 1937. Idem. II. Ibid., 5 (7), 167-244.

Verma, S. C. 1936. Studies on the family Bucephalidae (Gasterostomata). Pt. I. Proc. Nat. Acad. Sc. Ind., 6 (1), 66-89. 1936. Idem. Pt. II. Ibid., 6 (3), 252-260.

Yamaguti, S. 1934. Studies on the helminth fauna of Japan. Pt. 2. Trematodes of fishes, I. Jap. J. Zool., 6, 159-182. 1938. Idem. Pt. 21. Trematodes of fishes, IV. Published by author, $139 \mathrm{pp}$. 1942. Idem. Pt. 39. Trematodes of fishes mainly from Naha. Trans. Biogeogr. Soc. Jap., 3 (4), 329-398.

Zhukov, E. V. 1957. New genera and species of trematode parasites of fish in the Far Eastern Seas. Zool. Zhurn. Akad. Nauk, SSSR, 36 (6), 840-846. (In Russian) 


\section{EXPLANATION OF PLATES XX-XXI}

\section{Plate XX}

Fig. 1. Bucephalus sebastichthydis n. sp., ventral view.

Fig. 2. Dolichoenterum magnum n. sp., ventral view.

Fig. 3. Rhipidocotyle sphyraenae n. sp., ventral view.

Fig. 4. Rhynchus of Rhipidocotyle sphyraenae, ventral view.

Fig. 5. Plagioporus (Caudotestis) parapercis n. sp., ventral view.

Fig. 6. Decemtestis parapercis n. sp., ventral view.

Fig. 7. Plagioporus (Plagioporus) kyusen n. sp., ventral view.

Fig. 8. Allolasiotocus nibeae n. g., n. sp., ventral view.

\section{Plate XXI}

Fig. 9. Deretrema parapriacanthi n. sp., ventral view.

Fig. 10. Opegaster elongata $\mathrm{n}$. sp., ventral view.

Fig. 11. Maculifer chilomycteri $\mathrm{n}$. sp., ventral view.

Fig. 12. Lepidophyllum canthigastris n. sp., ventral view.

Fig. 13. Pseudoheterolebes chilomycteri n. sp., ventral view.

Fig. 14. Allodidymozoon sphyraenae n. sp., ventral view.

Uterus in hindbody omitted.

Fig. 15. Anterior extremity of forebody of Allodidymozoon sphyraenae, ventral view.

\section{Abrreviations USED in Figures}

$\mathrm{AC}=$ acetabular collar,$\quad \mathrm{AN}=$ anus,$\quad \mathrm{C}=$-cirrus, $\mathrm{CP}=$ cirrus pouch, $\mathrm{D}=$ vas deferens, $\mathrm{E}=$ esophagus, $\mathrm{EP}=$ excretory pore, $\mathrm{F}=$ forebody, $\mathrm{GA}=$ genital atrium, $\mathrm{GP}=$ genital pore, $I=$ intestine, $\mathrm{LC}=$ Laurer's canal, $\mathrm{M}=$ metraterm, $\mathrm{MT}=$ mouth, $\mathrm{N}=$ nerve commissure, $\mathrm{O}=$ ovary, $\mathrm{P}=$ pharynx, $\mathrm{PO}=$ postoral ring, $\mathrm{PR}=$ prostatic cell, $\mathrm{R}=$ rhynchus, $\quad R S=$ receptaculum seminis, $S G=$ shell gland, $\quad T=$ testis, $\quad T A=$ tentacular appendage, $\quad \mathrm{U}=$ uterus, $\mathrm{V}=$ excretory vesicle, $\mathrm{VR}=$ vitelline reservoir, $\mathrm{VT}=$ vitellaria. 
Publ. Seto Mar. Biol. Lab., VII, 2 (1959)

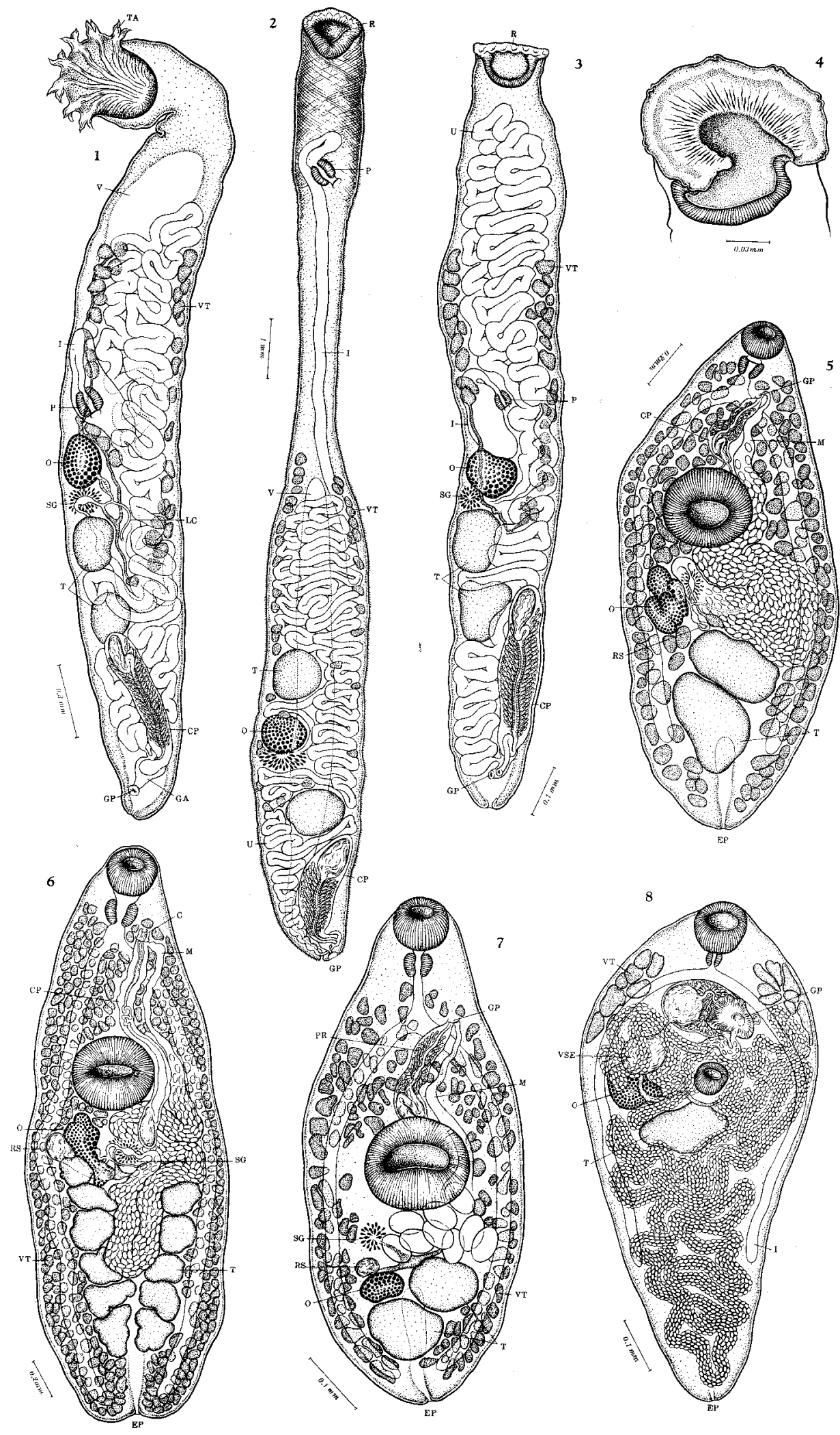

S. Yamaguti : Studies on the Helminth Fauna of Japan, 54. 
Publ. Seto Mar. Biol. Lab., VII, 2 (1959)

PLATE XXI
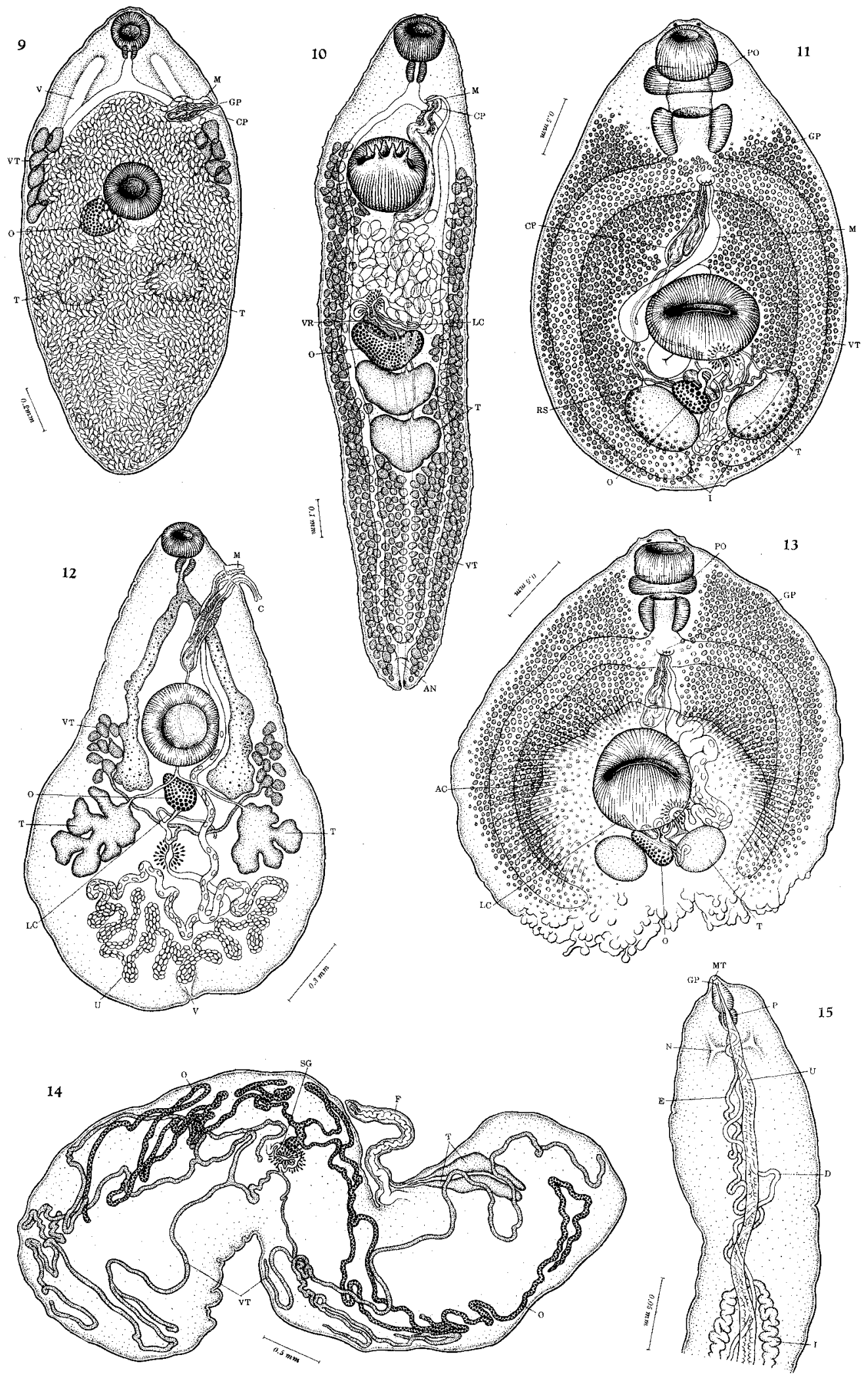

S. Yamaguti : Studies on the Helminth Fauna of Japan, 54. 